\title{
The Integration of The Multi-Source Data for Multi- Temporal Investigation of Cultural Heritage Objects
}

\author{
Jakub Markiewicz \\ Faculty of Geodesy and Cartography \\ Warsaw University of Technology \\ Warsaw, Poland \\ jakub.markiewicz@pw.edu.pl
}

\author{
Sławomir Łapiński \\ Faculty of Geodesy and Cartography \\ Warsaw University of Technology \\ Warsaw, Poland \\ slawomir.lapinski@pw.edu.pl
}

\author{
Agnieszka Bocheńska \\ Archaeology Department \\ The Royal Castle in Warsaw \\ Warsaw, Poland \\ abochenska@zamek-krolewski.pl
}

\author{
Magomed Muradov \\ BEST Research Institute \\ Liverpool John Moores University \\ Liverpool, United Kingdom \\ m.muradov@ljmu.ac.uk
}

\author{
Patryk Kot* \\ BEST Research Institute \\ Liverpool John Moores University \\ Liverpool, United Kingdom \\ p.kot@1jmu.ac.uk
}

\begin{abstract}
Nowadays, there are many techniques being developed to increase the knowledge of cultural heritage sites as there are many historical places where the knowledge about their construction and function is not well investigated yet. The example of such monument is the Justice Court Tower at Royal Castle in Warsaw where the excavation of the tower was carried out for archaeological and architectural research. This article demonstrates the integration of digital methods along with excavation work. Three measurement techniques were applied: the close-range terrestrial laser scanning and close-range photogrammetry as well as surveying. It was important to determine the potential route of the wall on the west side of the tower and to determine its relationship with the lowest part of its foundations. The results confirmed that the Tower collapsed in the Middle Ages. The building that has survived to the present day is another one erected on this site. At least two construction phases have been distinguished in the foundation structure. The relic of the wall adjacent to it from the west could have been an element of earlier buildings integrated with the Tower or an autonomous edifice. The study of the torsion angles of the surfaces of the lowest foundation layers in relation to slightly younger upper levels and the parallelism of both adjacent structures allowed to finally resolve this issue.
\end{abstract}

Keywords-Cultural Heritage, multi-temporal analysis, point clouds, Structure-from-Motion (SfM), Terrestrial Laser Scanning (TLS)

\section{INTRODUCTION}

Nowadays, many researchers are developing different methods for documentation, management, and sustainability of cultural heritage objects and sites. Commonly for this purpose, the close-range photogrammetric methods, namely image - (i.e. Structure-from-Motion with Multi-View Stereo) and range-based (i.e. Terrestrial Laser Scanning - TLS), as well as classical surveying, are used [1]-[12]. Commonly the result of this investigation is the documentation in the form of the 3D point clouds, 3D models, vector drawings and orthoimages supported by the archival documentation stored in the geographical information systems (GIS). It should also be highlighted that GIS allows for extended spatial analysis and multi-temporal and multi-source data integration.

The image- and range-based measurement techniques applied for 3D shape reconstructions have advantages and disadvantages [10], [13]. Table I synthetic summaries the advantages and disadvantages of the above-mentioned methods.

TABLE I. THE SYNTHESIS OF THE CLOSE-RANGE PHOTOGRAMMETRY AND LASER SCANNING TECHNIQUES AND CHARACTERISTICS [13]

\begin{tabular}{|c|c|c|}
\hline Characteristics & $\begin{array}{c}\text { Photogrammetry } \\
\text { (image-based) }\end{array}$ & $\begin{array}{c}\text { Terrestrial Laser } \\
\text { Scanning } \\
\text { (image-based) }\end{array}$ \\
\hline Cost of theinstruments & Low & High \\
\hline Manageability/Portability & Excellent & Sufficient \\
\hline Time of data acquisition & Quite short & Generally long \\
\hline Distance's dependence & Independent & Dependent \\
\hline Dimension's dependence & Independent & Dependent \\
\hline Material's dependence & $\begin{array}{c}\text { Almost } \\
\text { independent }\end{array}$ & $\begin{array}{c}\text { Dependent } \\
\text { Light's dependence }\end{array}$ \\
\hline Dependent & Almost \\
\hline Geometry'sdependence & Quite dependent & Independent \\
\hline Scale & Absent & Implicit (1:1) \\
\hline
\end{tabular}

Nowadays, because photogrammetric and terrestrial laser scanning techniques have advantages and limitations, it is common to integrate both methods during the investigation of cultural heritage objects and sites [2]-[4], [6], [7], [14]-[20].

This article aims to present the novel method of multisource and multi-temporal data processing and integration for extended architectural spatial and historical analysis based on the case study carried out at the Justice Court Tower at the Royal Castle in Warsaw (Fig. 1).

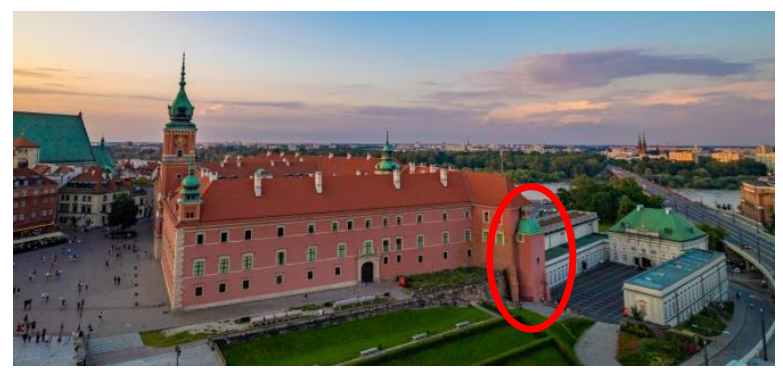

Fig. 1. The Royal Castle in Warsaw with marked Justice Court Tower (copyright Royal Castel in Warsaw). 


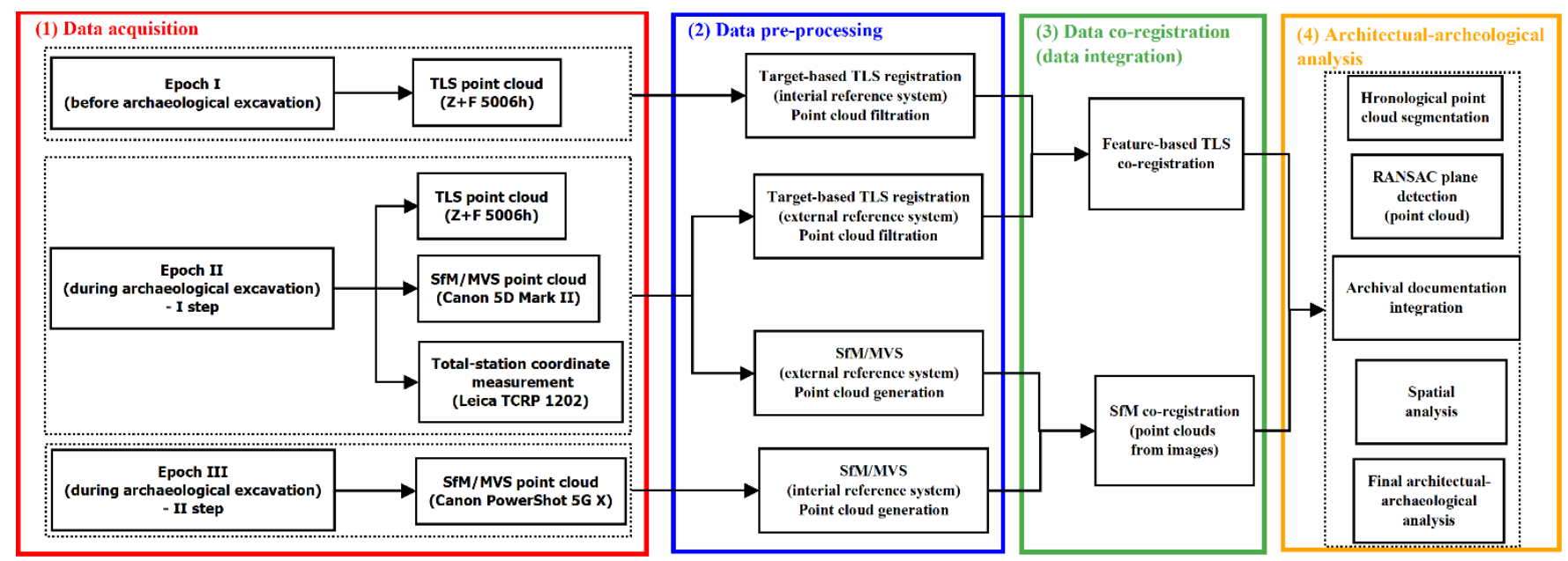

Fig. 2. The block diagram of the performed experiment.
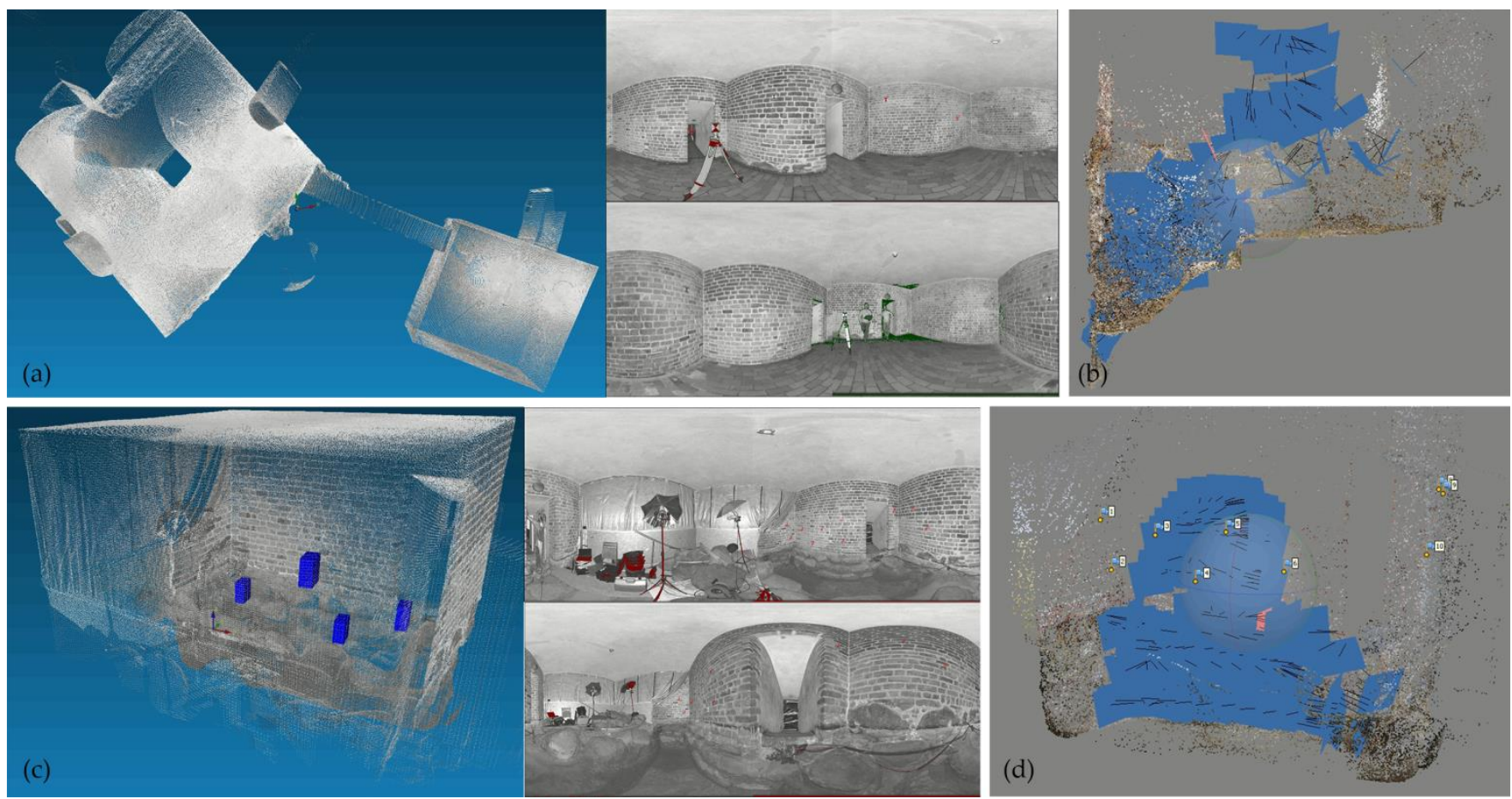

Fig. 3. The example of TLS point clouds from (a) Epoch I (left side 3D point cloud, right point clouds in spherical projections), (c) Epoch II, and image-based point clouds from 9b) Epoch III and (d) Epoch II.

\section{The Royal CASTLE IN WARSAW}

The Royal Castle in Warsaw, currently functioning as a museum. Over the years of existence and its detailed history, it has grown to the rank of a symbol of statehood, power, or freedom. It seemed that its history ended during World War II when it was utterly destroyed. However, thanks to the efforts of many people, it was raised from the rubble and still stands on the Vistula embankment.

Despite the fact that it is an almost entirely reconstructed object, a number of relics from various historical periods have been preserved in its walls. However, knowledge about the functioning of the Warsaw stronghold in its oldest stages is unclear. The image of the past was effectively obliterated by the numerous transformations that the stronghold and later the castle underwent. Archaeological and architectural research provided a certain amount of information. A special place is the oldest, preserved in part of the ground floor building, that is part of the castle complex - the Justice Court Tower and its surroundings. The archaeological and architectural research conducted here at various periods allowed for the formulation of a theory about the origins of the Warsaw Castle.

\section{THE OVERVIEW OF THE METHOD}

To carry out the surveying with photogrammetric measurements and architectural-archaeological analysis, two measurements techniques were used: the close-range terrestrial laser scanning with $\mathrm{Z}+\mathrm{F}$ 5006h and close-range photogrammetry Canon 5D Mark II and low-cost Canon PowerShot G5X. The data acquisition and processing pipeline was divided into the four main parts (1) Data acquisition, (2) Data pre-processing, (3) Data co-registration and (4) Spatial and historical analysis (Fig. 2).

\section{A. Data acquisition}

Data was acquired during three Epochs (Fig. 3): 
- the primary documentation before the archaeological excavation - TLS measurement with Z+F 5006h with resolution $6.1 \mathrm{~mm} / 10 \mathrm{~m} ; 10 \mathrm{TLS}$ stations - Epoch I,

- the first step of archaeological excavation - TLS measurement with $\mathrm{Z}+\mathrm{F}$ 5006h with resolution 6.1 $\mathrm{mm} / 10 \mathrm{~m} ; 4$ TLS stations; image acquisition with Canon 5D Mark II and Total Station measurement with Leica TCRP 1202 with angular accuracy 2 sec., linear accuracy $2 \mathrm{~mm}+2 \mathrm{ppm}$ - Epoch II,

- the final step of archaeological excavation - images acquisition with low-cost Canon PowerShot G5XEpoch III. The TLS data could not be collected at this step as the equipment was to close to the measurement surface.

For determining the first order geodetic control network, measurements were performed using the Leica TCRP 1202 total station, which allows measurement of angles of 1 " and reflector distance measurement of $2 \mathrm{~mm}+2 \mathrm{ppm}$. To determine the first-order reference system, the three-tripod method was used [21]. This method consisting of placing three stations, one instrument and two prisms and perform the measure between the stands without the relative movement.

\section{B. Data pre-processing}

The process of TLS data pre-processing consists of two sub-process: The first step is the Target-based registration process that relies on the detection of corresponding points in at least two point clouds and determination of the exterior orientation parameters [3], [22]. These parameters determine the spatial location of the central point of the point cloud in the assumed reference system together with three rotation angles, which determine the angular rotation of the point cloud. For the pre-processing TLs point cloud registration, the $\mathrm{Z}+\mathrm{F}$ LaserControl software was used. In the pre-processing step, the point clouds from Epoch I were registered in the local reference system related to the scan in the Justice Court Tower (Fig. 3a). In Epoch II, all points were oriented in the exterior reference system based on points with well-known coordinates. The results of the registration were presented in Table II.

TABLE II. THE RESULTS OF TLS TARGET-BASED REGISTRATION

\begin{tabular}{|c|c|c|}
\hline \multirow{2}{*}{ Factor } & \multicolumn{2}{|c|}{ TLS Target-based registration results } \\
\cline { 2 - 3 } & Epoch I & Epoch II \\
\hline Average Deviation $[\mathrm{mm}]$ & 1.3 & 1.5 \\
\hline Standard Deviation $[\mathrm{mm}]$ & 0.7 & 0.8 \\
\hline Maximal Deviation $[\mathrm{mm}]$ & 2.6 & 5.1 \\
\hline
\end{tabular}

After the TLS registration process, the filtration step was adopted, which relies on removing outliers based on the intensity filtration and statistical outlier removal [23].

The process orientation and dense point cloud generation of the close-range images include photographs taken during the Epoch II (first step of archaeological excavations; 275 images taken with Canon 5D Mark II) and Epoch III (the last stage of archaeological excavation, images taken with the lowcost Canon PowerShot G5X camera; 380 photographs) was performed in the Agisoft Metashapes software. In Table III the initial parameters with the orientation results and dense point cloud information were presented.
TABLE III. THE RESULTS OF TL S TARGET-BASED REGISTRATION

\begin{tabular}{|c|c|c|c|c|}
\hline \multicolumn{5}{|c|}{ Initial Parameters - Epoch II and III } \\
\hline \multicolumn{3}{|c|}{ Orientation } & \multirow{2}{*}{\multicolumn{2}{|c|}{$\begin{array}{c}\text { Dense Point Cloud } \\
\text { Pyramid level }\end{array}$}} \\
\hline Accuracy & \multicolumn{2}{|c|}{ High } & & \\
\hline Pair preselection & \multicolumn{2}{|c|}{ No } & Medium & $\begin{array}{l}1 / 4 \text { image } \\
\text { resolution }\end{array}$ \\
\hline \multirow{2}{*}{ No. of tie points } & $\begin{array}{l}\text { Epoch } \\
\text { II }\end{array}$ & $\begin{array}{l}\text { Epoch } \\
\text { III }\end{array}$ & \multicolumn{2}{|c|}{ Filtration parameter } \\
\hline & 548,267 & 177,245 & \multicolumn{2}{|c|}{ Aggressive } \\
\hline \multicolumn{5}{|c|}{ Orientation accuracy } \\
\hline Parameter & \multicolumn{2}{|c|}{ Epoch II } & \multicolumn{2}{|c|}{ Epoch III } \\
\hline $\begin{array}{l}\text { RMS Reprojection } \\
\text { error [pix] }\end{array}$ & \multicolumn{2}{|c|}{0.7} & \multicolumn{2}{|c|}{1.1} \\
\hline $\begin{array}{c}\text { Max Reprojection } \\
\text { error [pix] }\end{array}$ & \multicolumn{2}{|c|}{2.2} & \multicolumn{2}{|c|}{3.8} \\
\hline $\begin{array}{l}\text { RMS reprojection } \\
\text { error on control } \\
\text { points [pix] }\end{array}$ & \multicolumn{2}{|c|}{$\mathrm{X}$} & \multicolumn{2}{|c|}{0.8} \\
\hline $\begin{array}{c}\text { RMS reprojection } \\
\text { error on check points } \\
\text { [pix] }\end{array}$ & \multicolumn{2}{|c|}{$\mathrm{X}$} & \multicolumn{2}{|c|}{0.4} \\
\hline $\begin{array}{l}\text { RMSE on control } \\
\text { points }\end{array}$ & \multicolumn{2}{|c|}{$\mathrm{X}$} & \multicolumn{2}{|c|}{$3.2 \mathrm{~mm}$} \\
\hline $\begin{array}{l}\text { RMSE on check } \\
\text { points }\end{array}$ & \multicolumn{2}{|c|}{$\mathrm{X}$} & \multicolumn{2}{|c|}{$3.0 \mathrm{~mm}$} \\
\hline
\end{tabular}

\section{Data co-registration}

Since data from different periods were oriented in internal reference system (the primary documentation and from the final step of archaeological excavation) and exterior reference system (the first step of archaeological excavation), it was necessary to perform the co-registration step with the featurebased orientation method [3], [22]. Depends on the source of data, different approaches were used. In the point cloud generated from the set of images, the in-build Agisoft Metashape feature-based algorithm was used (Table IV).

TABLE IV. THE RESULTS OF THE PROCESSING OF THE PHOTOGRAPHS WITH THE STRUCTURE-FROM-MOTION CO-REGISTRATION

\begin{tabular}{|c|c|c|}
\hline Parameter & [without unit] & [pix] \\
\hline No. of tie points & 56169 & $\mathrm{x}$ \\
\hline RMSE reprojection error & 0.23 & 1.3 \\
\hline Max reprojection error & 1.8 & 26.2 \\
\hline Mean keypoint size & $\mathrm{x}$ & 5.7 \\
\hline
\end{tabular}

For TLS point cloud registration authors' software method was used [3], [22], [24], which contains the following functionality: (1) conversion of the point cloud into the orthoimages with depth maps, (2) detection of the keypoints with BRISK, FAST, CenSure and SURF detector, (3) keypoint description (2D SIFT descriptor) and descriptor matching, (4) outliers detection and geometrical verification with relative parameters computation (RANSAC method), (5) automatic division of detected tie points into the control and check and (6) all point clouds transformation into the exterior reference system. The results of the performed co-registration was shown in Table V. 
TABLE V. TLS REGISTRATION RESULTS

\begin{tabular}{|l|l|c|c|c|c|c|c|}
\hline \multirow{2}{*}{$\begin{array}{c}\text { Detector/ } \\
\text { Method }\end{array}$} & \multicolumn{6}{|c|}{$\begin{array}{c}\text { No of } \\
\text { control/check } \\
\text { points }\end{array}$} & \multicolumn{2}{|c|}{ RMSE on ctrl points } & \multicolumn{4}{c|}{$\begin{array}{c}\text { RMSE on } \\
\text { check points }\end{array}$} \\
\cline { 2 - 9 } & $\begin{array}{c}\mathrm{X} \\
{[\mathrm{mm}]}\end{array}$ & $\begin{array}{c}\mathrm{Y} \\
{[\mathrm{mm}]}\end{array}$ & $\begin{array}{c}\mathrm{Z} \\
{[\mathrm{mm}]}\end{array}$ & $\begin{array}{c}\mathrm{X} \\
{[\mathrm{mm}]}\end{array}$ & $\begin{array}{c}\mathrm{Y} \\
{[\mathrm{mm}]}\end{array}$ & $\begin{array}{c}\mathrm{Z} \\
{[\mathrm{mm}]}\end{array}$ \\
\hline BRISK & $70 / 13$ & 1.7 & 2.0 & 2.4 & 2.1 & 2.3 & 1.7 \\
\hline FAST & $9521 / 13$ & 1.8 & 1.7 & 2.2 & 2.2 & 2.2 & 1.8 \\
\hline CenSure & $821 / 13$ & 1.8 & 1.5 & 2.1 & 2.2 & 2.2 & 2.0 \\
\hline SURF & $2877 / 13$ & 1.4 & 1.3 & 1.5 & 2.3 & 2.4 & 2.1 \\
\hline
\end{tabular}

The data analysis shows that accuracy on natural control and check points for all detectors is similar and do not exceed $2.5 \mathrm{~mm}$. The values of control points (used for the TLS registration parameters computation) and check points (used for the independent analysis) are approximately the same, proving that the TLS registration process was correct. The main difference is in the number of points. The highest number was obtained by the SURF and FAST detector and the lowest for BRISK detector.

\section{RESULTS: ARCHITECTURAL-ARCHEOLOGICAL ANALYSIS}

The shape of the Warsaw castle in the Middle Ages is still not confirmed. The core of the foundation was the Tower surrounded on the west side by a moat. It was identified that the building with the Justice Court Tower, has survived to this day. Therefore, a detailed analysis of its base structure may be crucial in the context of knowledge about the original buildings of the Warsaw stronghold [25], [26].

The Justice Court Tower, whose construction dates to the third quarter of the 14th century, is the oldest surviving building of the castle complex, but it was not the first brick structure. This is evidenced by the relic of the brick wall foundation on its eastern side, to which it was added. The fate of the building that was its predecessor is unknown.

During the research carried out inside it in 2018, the foundation of the northern wall of the tower was fully exposed. This allowed for observations and detailed analyses of this structural element (Fig. 4).

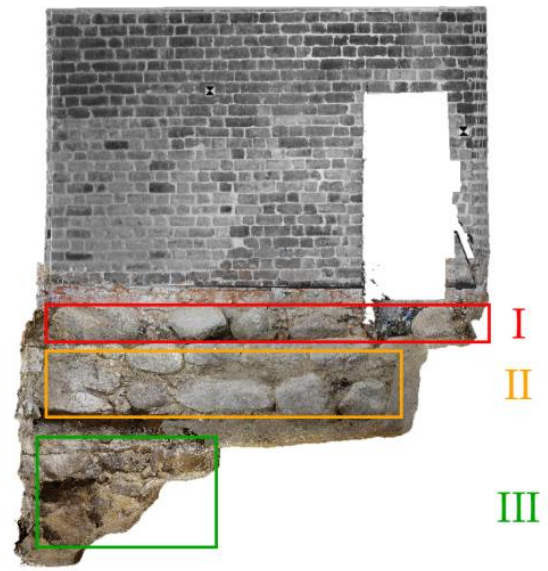

Fig. 4. The orthoimage of the northern wall of the Justice Court Tower with extracted layers of the foundation.

Its northern foundation was built using a stepped method of eratite boulders connected with lime mortar mixed with brick rubble. At its western end, with the height of 3 meters, and at the eastern end, it was only about $60 \mathrm{~cm}$. It follows that the tower structure was based on a hill sloping gently towards the west [27]. It is possible that the hill was previously artificially covered, as evidenced by geological drilling.

Some structural differences were observed in the arrangement of individual layers that make up the northern foundation (Fig. 4). Three levels were distinguished, differing in terms of the method of elaboration. In order to determine the spacing between the different layers, it was decided to analyse the skewness of the plane fitted into the points forming the foundations (Fig. 5). The discrepancies between the angles of the created surfaces, reaching approx. $20 \mathrm{~cm}$, confirm the heterogeneity of the structure and indicate at least two-phase in its functioning.

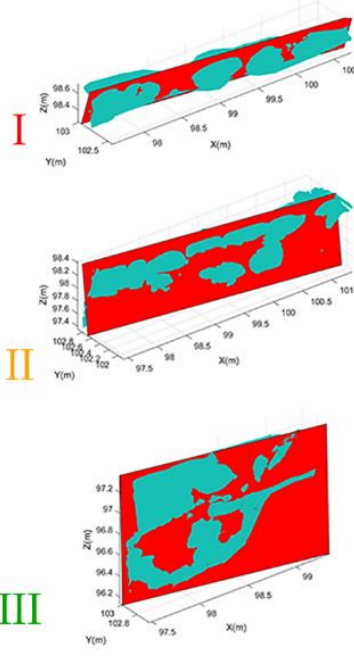

(a)
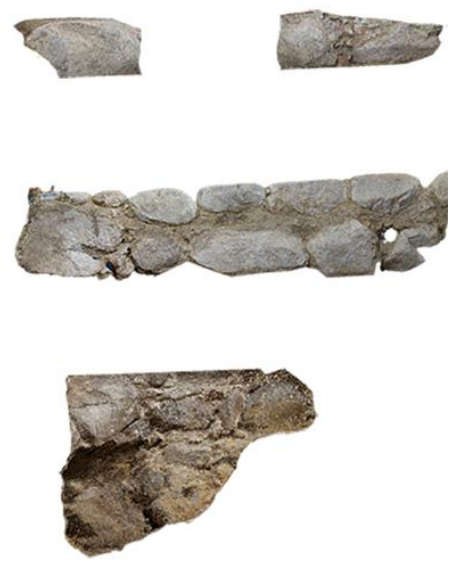

(b)

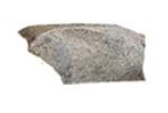

Fig. 5. The examples of the plane fitted (a) into the segmented and filtered point clouds (b).

One of the analytical assumptions was to examine the relationship between the lowest part of the foundation and the relic mentioned above of the oldest wall. Studies of bricks that were used to fill the space between the boulders indicate the probability that this part of the base is slightly older than the upper parts. To determine their chronology, an innovative method of thermoluminescence dating was used, consisting of determining the time of creating objects heated during the production process, use or a random event to a temperature of at least 350 degrees C. Among the absolute dating methods, this method is distinguished by the fact that the obtained age is given in calendar years. The obtained dates point to the beginning of the 14th century. Analysis of the bricks used in the construction of the Tower, using the same method, showed that they come from the $3^{\text {rd }}$ quoter of the 14 th century. The chronological difference is also indicated by another way of treating stones placed on a higher level. The base of this part of the foundation consists of two rows of smoothly polished stones with regular, cuboid-like shapes. There was a visible twisting of the surface created in relation to the other parts. It follows that the building, fragments of which have survived to this day, was built using an earlier assumption. The Great Tower was unlucky in the past. There are traces of an undetermined construction disaster in written sources. In documents from the end of the 15th and the beginning of the 16th century, the description of the plots and their location 
suggests the tower's turbulent fate: turris rupte, fracte, collapse - broken, overturned tower. The details of this event are not known, and there is no information as to what extent the tower was damaged. It is, therefore, possible that the building was rebuilt using the remains of an earlier edifice.

There is also no information about the western wall to which the upper part of the Tower was added. It is not known whether it was part of an earlier building or a fragment of the defensive wall. It was likely that the lowest part of the Tower's foundation comes from the same period as the relic mentioned above located on the west side of the tower. The analysis of the angles was aimed at checking whether both structures could have belonged to the same building in the past or whether they were two separate blocks. This analysis was necessary to integrate the archival vector drawing with actual point clouds in the GIS software. The archival vector drawing materials were created during architectural research aimed at inventorying the walls of the Royal Castle that survived the destruction during World War II. The study was made by Ing. arch. Antoni Kąsinowski in 1960 in connection with the planned conservation works and plans for the reconstruction of the Castle. The background material for the drawings was made of prints from a matrix by Kazimierz Skórewicz, dating from the interwar period and updated in 1952 [28].

The process of the vector drawing rectification and registration in the assumed reference system contains the following steps: (1) importing of the integrated point clouds into the ArcGIS, (2) extract lines (walls) from point cloud with Hough's transform [29], (3) scanned vector drawing was rectified and transformed - based on the detected corners on extracted from walls lines and archival vector drawing and (4) final parallelism analysis. The results of the process mentioned above were presented in Figure 6.

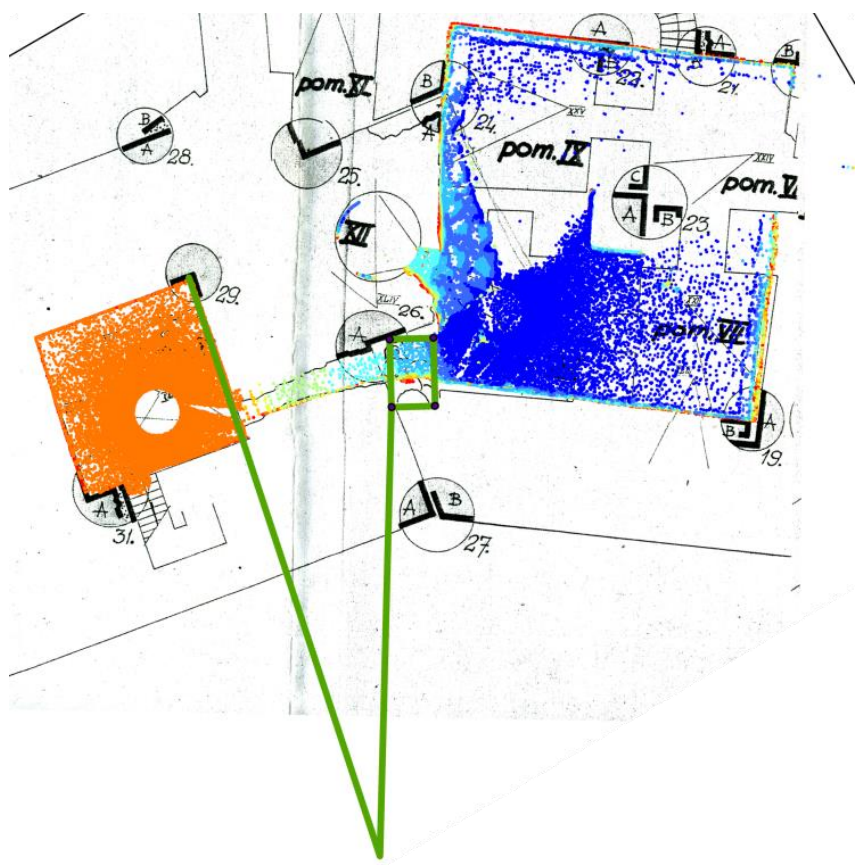

Fig. 6. The archival vector drawing with marked tested construction parts.

The obtained results made it possible to state that there were two separate constructions unequivocally. The parallelism between them is $34.5773^{\circ}$. Mapping the probable angles of the geometry of both objects indicates the lack of direct relations

\section{SUMMARY}

This research aimed at learning about the history of specific site the Justice Court Tower at the Royal Castle in Warsaw. The used methods in this research enabled to increase the historical knowledge of an object and to recognize new values that allow to determine its function in the past. There is no sufficient hard evidence that would allow to indicate the exact time when the first buildings on the Vistula embankment were built and to determine the shape of the buildings. The archaeological and architectural research together with the proposed modern documentation methods are less exposed to the risk of serious measurement errors. In the so-called urban archeology architectural relics occupy a special place, objects of smaller or larger dimensions, embedded in a specific spatial context and subject to frequent transformations. The use of a combination of stratigraphic and digital measurements allows to obtain an active threedimensional model, facilitating the study of interrelationships. The performed analysis allowed for the verification of the adopted assumptions and gave the final answer to the mutual relations of both historic relics.

\section{REFERENCES}

[1] E. Abbate, G. Sammartano, and A. Spanò, "PROSPECTIVE UPON MULTI-SOURCE URBAN SCALE DATA FOR 3D DOCUMENTATION AND MONITORING OF URBAN LEGACIES," ISPRS - Int. Arch. Photogramm. Remote Sens. Spat. Inf. Sci., vol. XLII2/W11, pp. 11-19, May 2019, doi: 10.5194/isprs-archives-XLII-2-W11-112019.

[2] R. Arif and K. Essa, "Evolving Techniques of Documentation of a World Heritage Site in Lahore," ISPRS - Int. Arch. Photogramm. Remote Sens. Spat. Inf. Sci., vol. XLII-2/W5, no. September, pp. 33-40, 2017, doi: 10.5194/isprs-archives-XLII-2-W5-33-2017.

[3] J. Markiewicz, S. Lapiński, A. Bocheńska, and P. Kot, "THE RELIABILITY ASSESSMENT OF THE TLS REGISTRATION METHODS - THE CASE STUDY OF THE ROYAL CASTLE IN WARSAW," Int. Arch. Photogramm. Remote Sens. Spat. Inf. Sci., vol. XLIII-B2-2, pp. 855-861, Jun. 2021, doi: 10.5194/isprs-archives-XLIII-B22021-855-2021.

[4] A. Bocheńska, J. Markiewicz, and S. Łapiński, "THE COMBINATION of the IMAGE and RANGE-BASED 3D ACQUISITION in ARCHAEOLOGICAL and ARCHITECTURAL RESEARCH in the ROYAL CASTLE in WARSAW," in International Archives of the Photogrammetry, Remote Sensing and Spatial Information Sciences - ISPRS Archives, 2019, vol. 42, no. 2/W15, doi: 10.5194/isprs-archives-XLII-2W15-177-2019.

[5] L. Cipriani, S. Bertacchi, and G. Bertacchi, "AN OPTIMISED WORKFLOW FOR THE INTERACTIVE EXPERIENCE WITH CULTURAL HERITAGE THROUGH REALITY-BASED 3D MODELS: CASES STUDY IN ARCHAEOLOGICAL AND URBAN COMPLEXES," ISPRS - Int. Arch. Photogramm. Remote Sens. Spat. Inf. Sci., vol. XLII2/W11, pp. 427-434, May 2019, doi: 10.5194/isprs-archives-XLII-2-W11427-2019.

[6] P. Grussenmeyer and J. Yasmine, "Photogrammetry for the Preparation of Archaeological Excavation. A 3D Restitution According to Modern and Archive Images of Beaufort Castle landscape (Lebanon), Int. Arch. Photogramm. Remote Sens., vol. XXXV, part, pp. 809-814, 2004, [Online]. Available: http://hal.archivesouvertes.fr/docs/00/26/40/14/PDF/Grussenmeyer_Yasmine_ISPRS_Istanbu 12004.pdf.

[7] J. N. Hatzopoulos, D. Stefanakis, A. Georgopoulos, S. Tapinaki, V. Pantelis, and I. Liritzis, "Use of various surveying technologies to 3D digital mapping and modelling of cultural heritage structures for maintenance and restoration purposes: The Tholos in Delphi, Greece," Mediterr. Archaeol. Archaeom., vol. 17, no. 3, pp. 311-336, 2017, doi: 10.5281/zenodo. 1048937

[8] V. Heras, E. Sinchi, J. Briones, and L. Lupercio, "URBAN HERITAGE MONITORING, USING IMAGE PROCESSING TECHNIQUES AND DATA COLLECTION WITH TERRESTRIAL 
LASER SCANNER (TLS), CASE STUDY CUENCA - ECUADOR," ISPRS - Int. Arch. Photogramm. Remote Sens. Spat. Inf. Sci., vol. XLII2/W11, pp. 609-613, May 2019, doi: 10.5194/isprs-archives-XLII-2-W11609-2019.

[9] P. Kot et al., "Combination of the photogrammetric and microwave remote sensing for Cultural Heritage documentation and preservation - preliminary results," Int. Arch. Photogramm. Remote Sens. Spat. Inf. Sci. - ISPRS Arch., vol. 43, no. B2, pp. 1409-1413, 2020, doi: 10.5194/isprs-archives-XLIII-B2-2020-1409-2020.

[10] Tobiasz, Markiewicz, Łapiński, Nikel, Kot, and Muradov, "Review of Methods for Documentation, Management, and Sustainability of Cultural Heritage. Case Study: Museum of King Jan III's Palace at Wilanów," Sustainability, vol. 11, no. 24, p. 7046, 2019, doi: 10.3390/su11247046.

[11] J. Markiewicz et al., "The quality assessment of different geolocalisation methods for a sensor system to monitor structural health of monumental objects," Sensors (Switzerland), 2020, doi: $10.3390 / \mathrm{s} 20102915$.

[12] F. Remondino and S. El-hakim, "Image-based 3D modelling: A review," Photogrammetric Record, vol. 21, no. 115. pp. 269-291, 2006, doi: 10.1111/j.1477-9730.2006.00383.x.

[13] S. Gonizzi Barsanti, F. Remondino, and D. Visintini, "3D Surveying and Modeling of Archaeological Sites - Some Critical Issues," ISPRS Ann. Photogramm. Remote Sens. Spat. Inf. Sci., vol. 2, no. 5/W1, pp. 145-150, 2013, doi: 10.5194/isprsannals-II-5-W1-145-2013.

[14] M. Sauerbier and H. Eisenbeiss, "Uavs for the Documentation of Archaeological Excavations," Proc. Isprs Comm. V Mid-Term Symp. Close Range Image Meas. Tech., vol. 38, no. 5, pp. 526-531, 2010.

[15] J. Markiewicz, D. Zawieska, A. Bocheńska, A. Tobiasz, and S. Łapiński, "The multitemporal photogrammetric data in archaeological and architectural research in the royal castle in Warsaw - First results," in International Archives of the Photogrammetry, Remote Sensing and Spatial Information Sciences - ISPRS Archives, 2018, vol. 42, no. 2, doi: 10.5194/isprs-archives-XLII-2-675-2018.

[16] S. Del Pozo et al., "Multispectral Imaging in Cultural Heritage Conservation," ISPRS - Int. Arch. Photogramm. Remote Sens. Spat. Inf. Sci., vol. XLII-2/W5, no. September, pp. 155-162, 2017, doi: 10.5194/isprsarchives-XLII-2-W5-155-2017.

[17] P. Drap et al., "Photogrammetry and Archaeological Knowledge: Toward a 3D Information System Dedicated to Medieval Archaeology: A Case Study of Shawback Castle in Jordan,” Int. Arch. Photogramm. Remote Sens. Spat. Inf. Sci., 2007, [Online]. Available: http://citeseerx.ist.psu.edu/viewdoc/download?doi=10.1.1.123.4711\&amp;r ep=rep1\&amp;type=pdf.

[18] S. Gonizzi Barsanti, F. Remondino, and D. Visintini, "3D surveying and modeling of archaeological sites \&ndash; Some critical issues \&ndash; Some," ISPRS Ann. Photogramm. Remote Sens. Spat. Inf. Sci., vol. 2, no. 5/W1, pp. 145-150, 2013, doi: 10.5194/isprsannals-II-5-W1-1452013.

[19] K. Koistinen, "Multitemporal archaeological imagery to model the progress of excavation," pp. 1006-1011, 2004, [Online]. Available: http://citeseerx.ist.psu.edu/viewdoc/download?doi=10.1.1.434.6708\&rep=r ep1\&type=pdf\%5Cnfiles/1035/Koistinen - 2004 - Multitemporal archaeological imagery to model the .pdf.

[20] J. Markiewicz, D. Zawieska, and P. Podlasiak, "Comparing multi-source photogrammetric data during the examination of verticality in a Monumental tower," Int. Arch. Photogramm. Remote Sens. Spat. Inf. Sci. - ISPRS Arch., vol. 42, no. 2W3, pp. 475-480, 2017, doi: 10.5194/isprsarchives-XLII-2-W3-475-2017.

[21] M. Minchin, Introduction to Surveying, Secod Edit. Department of Training and Workforce Development, 2003.

[22] J. Markiewicz and D. Zawieska, "The Influence of the Cartographic Transformation of TLS Data on the Quality of the Automatic Registration," Appl. Sci., vol. 9, no. 3, p. 509, Feb. 2019, doi: 10.3390/app9030509.

[23] H. Balta, J. Velagic, W. Bosschaerts, G. De Cubber, and B. Siciliano, "Fast Statistical Outlier Removal Based Method for Large 3D Point Clouds of Outdoor Environments," IFAC-PapersOnLine, vol. 51, no. 22, pp. 348-353, 2018, doi: 10.1016/j.ifacol.2018.11.566.

[24] J. Markiewicz and D. Zawieska, "Analysis of the Selection Impact of 2D Detectors on the Accuracy of Image-Based TLS Data Registration of Objects of Cultural Heritage and Interiors of Public Utilities," Sensors, vol. 20, no. 11, p. 3277, Jun. 2020, doi: 10.3390/s20113277.
[25] M. Sekuła, "Relikty umocnień obronnych odkrytych na dziedzińcu pałacu Pod Blachą," in Kronika zamkowa, Warsaw, 2007, pp. 91-111.

[26] A. Bocheńska, "Początki zamku Królewskiego w Warszawie," in Początki murowanych zamów w Polsce, A. Bocheńska and P. Mrozowski, Eds. Warsaw: Royal Castle in Warsaw, 2017, p. 154.

[27] A. Bocheńska, "Najnowsze odkrycia archeologiczne w Zamku Królewskim w Warszawie," Mówią Wieki, vol. 10/2018, p. 59, 2018.

[28] A. Kąsinowski, "Zespół piwnic gotyckich skrzydła wschodniego. Badania Architektoniczne," Warsaw, 1960.

[29] J. S. Markiewicz and D. Zawieska, "Generating orthoimages of monumental objects basing on integration of TLS data and digital images related issues and sources of errors," in International Multidisciplinary Scientific GeoConference Surveying Geology and Mining Ecology Management, SGEM, 2015, vol. 1, no. 2. 